\title{
Percutaneous Coronary Angioplasty in Diabetes Mellitus: Literature Review and Clinical Experience in Jakarta
}

\author{
N. Abdurahman
}

\begin{abstract}
Abstrak
Diabetes mellitus merupakan faktor resiko penting penyakit jantung koroner. Penderita diabetes umumnya mempunyai kelainan aterosklerotik yang lebih luas dan lebih berat. PTCA pada penderita diabet mempunyai angka keberhasilan yang tinggi dan komplikasi yang menyertainya umumnya rendah. Hal ini juga ditemukan pada penyelidikan kami. Walaupun harapan hidup jangka panjang cukup baik, penderita diabetes mellitus mempunyai kecendenungan untuk lebih sering mengalami infark dan menjalani tindakan revaskularisasi lebih lanjut, mungkin karena restenosis dini yang lebih sering dan progresi daripada penyakit jantung koroner dalam jangka panjang yang lebih cepat. Penderita diabetes mellitus yang telah mengalami operasi pintas koroner juga cenderung untuk mengalami progresi penyakit jantung koroner. Keuntungan dari PTCA dibandingkan operasi pintas koroner pada penderita diabetes mellitus belum jelas. Walaupun demikian, baru-baru ini dilaporkan (The Bypass Angioplasty Revascularization Investigation - BARI) bahwa harapan hidup lima tahun lebih baik pada pengobatan dengan operasi pintas koroner dibandingkan PTCA. Manfaat daripada alat-alat baru terutama pemasangan stent primer intra koroner masih dalam penyelidikan. Pada saat ini pengobatan terpilih masih belum jelas dan banyak ditentukan oleh dokternya. Walaupun demikian, pengobatan medik dengan modifikasi faktor resiko dan cara hidup yang baik tidak boleh dilupakan.Laporan ini membahas pengalaman klinik PTCA pada penderita diabetes mellitus di Jakarta. Data diambil dari 1000 penderita yang menjalani PTCA dimana 131 diantaranya menderita diabetes mellitus. Keberhasilan angiografik dicapai pada 316 dari 342 lesi $(92,4 \%)$ dan keberhasilan prosedur pada 118 dari 131 pasien $(90,1 \%)$. Seorang penderita menjalani operasi pintas koroner akut, dua mengalami infark miokard dan tidak ditemui kematian. Pengalaman kami menunjukkan bahwa PTCA pada penderita diabetes mellitus dapat dilaksanakan dengan angka keberhasilan yang tinggi dan komplikasi kardiak yang rendah. Kekerapan restenosis tak diketahui karena kebanyakan penderita kami tidak menjalani kateterisasi ulang untuk follow-up.
\end{abstract}

\begin{abstract}
Diabetes mellitus is a well-known risk factor for the development of atherosclerotic coronary artery disease. Diabetic patients usually have more extensive and more severe atherosclerotic disease. PTCA in diabetic patients is associated with high success and low complication rates, a finding which is also confirmed by our own study. Although long term survival is acceptable, diabetic patients may also have a higher rate of infarction and a greater need for additional revascularization procedures, probably because of early restenosis and late progression of coronary artery disease. Diabetes mellitus is also associated with progression of coronary artery disease in patients undergoing bypass surgery. The relative merits of PTCA compared to bypass surgery is still not clear. However, a recent report (The Bypass Angioplasty Revascularization Investigation-BARI) indicated that 5-year survival was better after initial treatment with bypass surgery than PTCA. The benefits of newer devices, particularly primary coronary stent implantation, are still being investigated in several studies. At present, the choice of management strategy is still undetermined and personal preference will play an important part in the decision process. However, medical therapy, with intensive risk factor and lifestyle modification, should never be dismissed. This report describes clinical experience with PTCA in the diabetic population in Jakarta. The data were derived from 1000 PTCA patients of whom 131 were diabetics. Angiographic success was achieved in 316 of 342 lesions (92.4\%) and procedural success in 118 of 131 patients $(90.1 \%)$. One patient underwent emergency coronary bypass surgery, two developed myocardial infarction and none died. Our experience showed that PTCA in the diabetics is associated with high success and low major adverse cardiac event rates. The prevalence of restenosis was unknown since the majority of the patients did not undergo repeat cardiac catheterization for angiographic follow up.
\end{abstract}

Keywords : Diabetes mellitus, Coronary artery disease, Angioplasty.

Division of Cardiology, Department of Internal Medicine, University of Indonesia Medical SchooV Dr. Cipto Mangunkusumo Hospital, Jakarta, Indonesia
Until insulin became available, the association of diabetes with atherosclerosis was virtually unknown. Survival of patients with diabetes before insulin was available was short and death was frequently at- 
tributable to ketoacidosis. ${ }^{1}$ The milder type of diabetes, now known as non-insulin dependent diabetes (NIDDM), was not widely recognizable and the clinical diagnosis of coronary artery disease was uncommon. Since 1920s a large number of studies have identified a high frequency of cardiovascular disease in diabetes and it is well established that coronary artery disease is a major complication of diabetes mellitus. However despite modern treatment the expectation of life of patients with diabetes is still considerably shorter than that of those without diabetes. ${ }^{2}$ The commonest cause of death in patients with diabetes mellitus is now atherosclerotic cardiovascular disease. $1,3,4$

The main purposes of the present paper are : (a) to review the association of diabetes mellitus and coronary artery disease, (b) to review the results of percutaneous transluminal coronary angioplasty ( PTCA ) and related procedures in patients with diabetes mellitus, (c) to review the results of PTCA as compared to coronary artery bypass surgery (CABG) in the diabetics, and (d) to present our own experience on PTCA in diabetic patients.

\section{Diabetes mellitus and coronary artery disease}

Much of epidemiological and clinical evidence associating diabetes with atherosclerosis has used as evidence of atherosclerosis clinical syndromes as myocardial infarction, angina pectoris, peripheral vascular disease and cerebrovascular disease. Although sudden death and congestive heart failure have also been used as end points, the latter categories are less clearly linked to atherosclerosis in the coronary circulation than the former. Accumulating evidence shows that patients with diabetes are predisposed to disease of the left ventricular myocardium that is not only due to coronary atherosclerosis but appears to be also a result of metabolic abnormalities in the heart muscle itself (diabetic cardiomyopathy). ${ }^{5}$ Epidemiological studies confirm that diabetes more than doubles the risk of cardiovascular disease. Diabetes removes the protective effect of the female sex in the development of atherosclerosis. These effects are independent of the effects of other cardiovascular risk factors. ${ }^{6-13}$

Coronary artery disease is the ultimate cause of death in more than half of all patients with diabetes mellitus. ${ }^{1,3,4}$ Furthermore, myocardial infarction in diabetic patients usually is more extensive and more severe than in nondiabetic patients. ${ }^{14-16}$ Cardiogenic shock $^{17}$ and cardiac failure ${ }^{18}$ are more common in diabetic patients with acute myocardial infarction. The long term survival rate after myocardial infarction among diabetic patients is also lower than that among nondiabetic patients. ${ }^{19}$ In fact, the 5 year survival rates for diabetic patients after the first major coronary event have been reported to be $38 \%$ and only $25 \%$ for those with subsequent events, compared with corresponding figures in nondiabetic patients of $75 \%$ and $50 \%$, respectively. ${ }^{14,15} \mathrm{An}$ increased prevalence of asymptomatic coronary artery disease ( including : silent myocardial ischemia and silent myocardial infarction ) in diabetic patients seems to be well established. The mechanism is unknown although diabetic autonomic neuropathy seems likely. It is probable that the high frequency of asymptomatic coronary artery disease contributes also to the poor prognosis of coronary artery disease in diabetics. 20,21

Autopsy studies are particularly significant as epidemiological and clinical studies usually rely on less direct methods of diagnosis of atherosclerosis. There is general agreement that coronary atherosclerosis is more severe at all ages and occurs at a younger age in diabetic than in nondiabetic patients. Atherosclerosis in diabetes is not related to the duration of the diabetes, the age of onset of the disease, the blood glucose levels or the type of treatment. $22-24$

Coronary angiography has also been used to compare the extent of atherosclerosis in diabetic and nondiabetic patients. The majority of angiographic studies have found that the diabetic patients had an increased number and severity of coronary stenosis, the difference between diabetic and nondiabetic patients being greater in women than in men. ${ }^{25-28}$

\section{PTCA and related procedures in diabetes mellitus}

PTCA is a useful and effective method of revascularization for many patients with atherosclerotic coronary artery disease. With tremendous advances in equipment design, angioplasty techniques, adjunctive procedures ( as coronary stenting, atherectomy etc. ) and pharmacological agents; PTCA has become far safer and more effective over the past 19 years. However, restenosis after PTCA remains a vexing problem.

Because of the prevalence of extensive atherosclerotic disease, diabetics constitute an important segment of the population undergoing PTCA.

Stein cs. have recently reported their large population study on the influence of diabetes mellitus on early and 
late outcome after PTCA. ${ }^{29}$ Data were derived from 1133 diabetic and 9300 nondiabetic patients undergoing elective PTCA from 1980 to 1990 at Emory University. Angiographic and clinical successes after PTCA were high and similar in diabetics and nondiabetics. In-hospital major complications were infrequent $(3 \%)$, with a trend toward higher death or myocardial infarction in insulin requiring diabetics. The reason for this worse outcome in insulin requiring diabetics is not entirely clear. Although insulin requiring diabetics had diabetes for a longer duration and worse renal and ventricular functions, and more multivessel disease compared with non-insulin requiring diabetics, insulin requirement was an independent correlate of decreased survival. On long term follow up, although five-year survival is acceptable $(89 \%$ in diabetics versus $93 \%$ in nondiabetics, $\mathrm{p}<0.0001$ ), diabetics have a higher rate of infarction $(81 \%$ versus $89 \%$ in nondiabetics, $\mathrm{p}<0.0001$ ) and a greater need for revascularization procedures ( bypass surgery or additional PTCA ). There are probably multiple reasons for this. First, coronary artery disease in diabetic patients is not only more prevalent, but also more extensive and more severe. Second, diabetics are known to be at higher risk of myocardial infarction. ${ }^{30}$ Most important pathogenic factors in myocardial infarction, namely atherosclerotic plaque fissuring and superimposed thrombosis, possibly occur more frequently in diabetic patients. ${ }^{31}$ Diabetics have hyperviscosity as a result of elevated plasma proteins, increased red cell aggregation, and/or decreased red cell deformability. ${ }^{32}$ Hyperviscosity, in turn, by increasing shear rate, may induce plaque rupture. Diabetics also have various hemorrheologic abnormalities that can predispose them to thrombosis. These include increased spontaneous and induced platelet aggregation ${ }^{33}$ enhanced synthesis of platelet thromboxane $\mathrm{A},{ }^{34}$ elevated measurements of platelet activation (platelet factor 4 and beta-thromboglobulin), ${ }^{35}$ increased procoagulant factors such as fibrinogen, factor VIII, and von Willebrand factor. ${ }^{33}$ In addition, hemostatic mechanisms aimed at reducing intravascular clotting may also be impaired. For example, synthesis of prostacycline is reduced and fibrinolysis is accentuated. ${ }^{33,35}$ Third, diabetics may exhibit an accelerated form of intimal hyperplasia and atherosclerosis in response to metabolic factors and to vascular injury caused by balloon dilatation. Hyperinsulinemia, common in non-insulin dependent diabetics with insulin resistance (and in insulin requiring diabetics treated with intermittent subcutaneous insulin ), may contribute to the atherogenic process. Insulin is a direct promoter of smooth muscle proliferation, and it may also increase cholesterol synthesis and increase the synthesis of growth factors. ${ }^{36,37}$ Together with the increased procoagulant state in diabetics, they may contribute directly to the progression of atherosclerosis.

The Emory data further showed that not only that repeated PTCA within the first year was more common in diabetics, but also that these patients required more frequent revascularization with either bypass surgery or PTCA during the five-year follow-up. Repeated PTCA during the first year was usually done because of restenosis , suggesting that diabetics are more prone to restenotic process. ${ }^{29}$ Other reports also suggested that diabetes mellitus increases the risk of restenosis. ${ }^{38-47}$ Revascularization after the first year is usually due to the progression of coronary artery disease.

As mentioned above, restenosis remains the Achilles heel of PTCA. Can restenosis be reduced with the application of newer devices?. The Emory data do not include patients undergoing PTCA and adjunctive procedures with these devices. At least two major studies (the BENESTENT ${ }^{48}$ and the STRESS ${ }^{49}$ trials ) suggested that to some extent, the use of intracoronary stent may reduce the rate of restenosis, the clinical event rate and the need of revascularization of the original coronary lesion. However, in the diabetic patients, new angioplasty devices failed to make any major impact on the restenosis rate. Diabetes is associated with a twofold increase in recurrent clinical events after directional coronary atherectomy. ${ }^{50}$ Likewise, diabetic patients have higher restenosis rate after intracoronary stent implantation ${ }^{51}$ and after excimer laser angioplasty. ${ }^{52}$

The relatively high restenosis rate after PTCA in diabetic patients is probably due to multiple factors. The metabolic alterations that occur as a result of hyperglycemia or hyperinsulinemia can accelerate many of the pathophysiologic process that lead to restenosis. ${ }^{53}$ Diabetes results in endothelial dysfunction, and alters the hemostatic mechanisms that can lead to further recruitment of platelets and mural thrombus formation. Several growth factors known to promote restenotic process are overexpressed in the presence of hyperglycemia. Growth factors that may be involved in the pathogenesis of restenosis in diabetic patients are : platelet derived growth factor (PDGF), insulin-like growth factor-1 (IGF-1), basic fibroblast growth factor (bFGF), transforming growth factor-beta (TGF-beta), endothelium derived growth 
factor (EDRF), endothelin-1 (ET-1), and heparan sulfate (HS). Furthermore, advanced glycosylation end products can mediate inflammatory cell recruitment and activation, stimulation of smooth muscle proliferation and abnormal matrix production, all of which can promote the restenosis process. ${ }^{53}$

Can restenosis rate in diabetic patients be reduced?. Further studies are required to assess whether pharmacologic interventions based on insights into the pathophysiologic mechanisms of restenosis using e.g..: growth factor inhibitors (e.g. : trapidil) ${ }^{54}$ new antithrombotic drugs, ${ }^{55}$ antiinflammatory agents and gene therapy ${ }^{54,56}$ may reduce restenosis rate. Many of the potential mechanisms promoting restenosis in diabetic patients are related to elevated glucose or insulin levels, or both. And the majority of these abnormalities are reversible on improved glycemic control. Therefore, simpler measures such as rigorous glycemic control may be expected to reduce the restenosis rate in diabetic patients. ${ }^{53}$ However, some of the above mentioned metabolic abnormalities may not be readily reversible. For example, hyperglycemia-induced gene transcription may persist for weeks after restoration of normoglycemia in vivo. This phenomenon may reflect irreversible intracellular and extracellular effects of hyperglycemia. Furthermore, normoglycemia is frequently achieved at the price of peripheral hyperinsulinemia. ${ }^{53}$

\section{PTCA versus bypass surgery in diabetes mellitus}

Diabetes mellitus is also associated with progression of coronary artery disease in patients who had undergone $\mathrm{CABG},{ }^{57}$

An important question is therefore : What are the relative merits of PTCA compared to CABG in diabetic patients? In their meta-analysis, Pocock and colleagues identified 8 prospective, randomized trials comparing PTCA and CABG enrolling a total of 3371 patients ( 1161 CABG, 1710 PTCA ) with chronic coronary artery disease. ${ }^{58}$ These trials were: Coronary Angioplasty versus Bypass Revascularization Investigation (CABRI), ${ }^{59}$ Randomized Intervention Treatment of Angina trial (RITA), ${ }^{60}$ Emory Angioplasty versus Surgery Trial (EAST) ${ }^{61}$ German Angioplasty Bypass surgery Investigation (GABI), ${ }^{62}$ The Toulouse Trial, ${ }^{63}$ Medicine Angioplasty or Surgery Study (MASS), ${ }^{64}$ The Lausanne Trial, ${ }^{65}$ and Argentine Trial of PTCA versus CABG (ERACI) ${ }^{65}$ Mean follow-up was 2.7 years (range 1 to 4.7 years). Despite variations in study design and patient characteristics ( such as number of diseased vessels and severity of angina ), the results from the eight trials were broadly consistent. The combined evidence comparing PTCA and CABG showed no difference in prognosis between these two initial revascularization strategies. Seventy nine (4.6\%) patients undergoing PTCA and 73 (4.4\%) undergoing $\mathrm{CABG}$ died during follow-up (relative risk $1.10 ; 95 \%$ confidence interval 0.79 to 1.50 ). Cardiac death or non-fatal myocardial infarction occurred in 169 (9.9\%) patients undergoing PTCA and 154 (9.3\%) undergoing $\mathrm{CABG}$ (relative risk $1.10 ; 95 \%$ confidence interval 0.89 to 1.37 ). At one year, CABG achieved complete relief of angina more often than did PTCA; although this difference diminished after 3 years of follow-up. Thirty four percent of patients undergoing PTCA required at least one other revascularization procedure during the first year of follow-up, including $18 \%$ who crossed over to $\mathrm{CABG} .{ }^{58}$

However, it should be acknowledged that restenosis is an established problem in the first 6 months after PTCA. The above trials have reported only a short follow-up period, sufficient to demonstrate the full effects of PTCA lesion restenosis but too short for the effects of new disease in the bypass grafts to become clinically apparent. The trials were also performed before the era of new devices, particularly intracoronary stent which has been demonstrated to lower the restenosis rate. ${ }^{48,49}$ Furthermore, patients undergoing PTCA may be less completely revascularized, because only clinically significant lesions were dilated.

It should also be noted that, coronary artery disease is in the main a progressive condition. Although intensive risk factor modification, particularly lipid lowering therapy, may have impact in this area it is likely that many patients will, over time, manifest a new atherosclerotic disease in native vessels and bypass conduits. Re-operation has a greater morbidity and mortality than the initial procedure and often threatens a patent and well functioning internal mammary artery conduit. Initial use of a PTCA-based strategy may allow CABG to be delayed or avoided, particularly in younger patients. ${ }^{67}$ This is further supported by the report of the angiographic sub-study of the German Angioplasty Bypass Investigation showing that the presence of a functioning bypass conduit may precipitate the occlusion of diseased, but previously patent, native vessels. ${ }^{68}$ Native vessel PTCA can sometimes be used as an alternative to reoperation in a patient with established graft disease but, when a bypass conduit has precipitated early occlusion, the value of this approach will be limited as PTCA success rates with chronic occlusions remains low. ${ }^{67}$ 
In the 8 trials mentioned above the number of patients with diabetes mellitus was relatively small to allow sub-group analysis to be done. In the meta-analysis of Pocock and colleagues, diabetes mellitus was also not mentioned. It is obviously hard to generalize the above findings to all patients, particularly the subgroup of patients with diabetes.

A recently published large population (1829 patients), long term study ( average follow-up period 5.4 years ) comparing PTCA versus CABG in patients with multivessel disease ( the Bypass Angioplasty Revascularization Investigation (BARI) Study), has shed some light to this. ${ }^{69}$ Most of the patients were at low or moderate risk of death. The report shows, that the 5-year survival rate of patients treated with PTCA or $\mathrm{CABG}$ was similar, although subsequent revascularization was required more often in the PTCAtreated group. Overall 5-year mortality was $13.7 \%$ in patients undergoing PTCA and $10.7 \%$ in those assigned to CABG; cumulative rates of myocardial infarction were $21.2 \%$ and $19.6 \%$, respectively. The observed $3.0 \%$ difference in absolute mortality represents a risk reduction of $22 \%$, but does not reach statistical significance. However, in treated diabetics, 5-year survival was significantly better after initial treatment with CABG than PTCA. Rihal and Yusuf commented that, a $20 \%$ difference in the risk of death between CABG or PTCA could be reliably shown only if at least 600 deaths occurred in the study population. This would mean enrolling about 16,000 patients at low risk or 8000 patients at moderate risk, and following them for 5 years. The significantly lower mortality associated with $\mathrm{CABG}$ in the subgroup of patients with diabetes in the BARI trial may therefore have been due to chance. ${ }^{70}$

Advances in techniques and equipment, particularly the use of coronary stents, have widened the scope and improved the results of PTCA. New trials are being planned or still underway, such as the Stent or Surgery Trial (SoS), the BENESTENT III or the ARTS trial. These trials will examine whether the benefits of primary stent implantation, established in isolated lesions, ${ }^{(48,49)}$ can be translated to multivessel setting. ${ }^{67}$ It is therefore still premature to know whether diabetic patients will also get the benefit from these new technology.

\section{METHODS}

From the latest 1000 patients undergoing elective PTCA, we identified 131 diabetic patients. The indications of PTCA were : Class II - IV angina if symptoms were poorly controlled with medical therapy or the patient was intolerant to antianginal medication; and in patients with no or mild symptoms, if a moderate large area of viable myocardium at risk and one of the following was present : a. severe ischemia on low level exercise testing, b. a history of myocardial infarction, hypertension and ischemic ST segment depression on ECG, c. hybernating myocardium. Patients were included in the diabetic group they receive active treatment for diabetes mellitus at the time of the initial PTCA. Diet controlled diabetics were included if a fasting blood sugar of $>140 \mathrm{mg} / \mathrm{dl}$ or a random blood sugar of $>200 \mathrm{mg} / \mathrm{dl}$ was documented during the hospitalization for PTCA ${ }^{71}$ Angina was classified according to the Canadian Cardiovascular Society. ${ }^{72}$ Single vessel disease was diagnosed if there was $\geq 75 \%$ narrowing in any of the major coronary artery or their major branches. Double or triple vessel disease was defined as the presence of $\geq 75 \%$ stenosis in either two or all three major epicardial vessels. Lesion morphology was determined into type $\mathrm{A}, \mathrm{B}$ or $\mathrm{C}$ according to the recommendation of the American College of Cardiology / American Heart Association Task Force. ${ }^{73}$ Ejection fraction was determined from pre-PTCA left ventriculogram. Angiographic success was defined as a reduction in the stenosis diameter of all lesions dilated to $50 \%$ and a decrease in the stenosis diameter by $>20 \%$. Clinical success was angiographic success in the absence of major adverse cardiac events including myocardial infarction, need for emergency CABG or death.

\section{RESULTS}

Of the 131 patients, 78 were male and 53 female. Their ages ranged from 34 to 78 years old (mean $59 \pm 11$ ). Prior hypertension was found in $73(55.7 \%)$ patients, prior myocardial infarction in $47(35.9 \%)$ patients, and poor ejection fraction $<50 \%$ in $19(14.5 \%)$ patients. Seventy six $(58.0 \%)$ patients had single vessel disease, $46(35.1 \%)$ had double vessel disease and $9(6.9 \%)$ had triple vessel disease. A total of 342 lesions were dilated (or 2.6 lesion / patient), of which 109 (31.9\%) were type A, 210 ( $58.8 \%$ ) were type B and $32(9.3 \%)$ were type $C$. Angiographic success was achieved in 316 of 342 lesions $(92.4 \%)$ and procedural success in 118 of 131 patients ( $90.1 \%$ ). One patient underwent emergency $\mathrm{CABG}, 2$ developed myocardial infarction and none of the patients died.

\section{DISCUSSION}

At the time this report was prepared, comparison was not made with data obtained from non-diabetic 
patients. Other limitations of the present study were lack of data regarding the duration, type of treatment, and adequacy of glycemic control of diabetes, and the prevalence of other risk factors such as cigarette smoking and dyslipidemia. Given the retrospective nature of the study, it has to be acknowledged that some data were missing. However, the angiographic and procedural success rates were comparable to the success rates of the whole PTCA patients ${ }^{74}$ and those reported in the literature. ${ }^{29,69}$ Because of cost consideration, the majority of the patients did not undergo repeat cardiac catheterization for angiographic follow-up; and therefore the prevalence of restenosis remains unknown.

\section{CONCLUSION}

The experience in Jakarta showed that PTCA in the diabetics is associated with high success and low major adverse cardiac event rates.

\section{Acknowledgment}

To T. Santoso, M.D., PhD. for his help in compiling the data.

\section{REFERENCES}

1. Marks HH, Krall LF. Onset course, prognosis and mortality in diabetes mellitus. In: Marble A, White P, Bradley RF, Krall LF (eds). Joslin's Diabetes Mellitus, Philadelphia : Lea \& Febiger, 1971: 209 - 54.

2. Stout RW. Diabetes mellitus and atheroserosis, In: Stout RW (ed.). Diabetes and atherosclerosis, Dordrecht : Kluwer Academic Publ. 1992 : 53 - 87

3. Palumbo PJ, Elveback LR, Chu CP, Connolly DC, Kurland LT. Diabetes mellitus : incidence, prevalence, survivorship, and causes of death in Rochester, Minnesota, $1945-1970$. Diabetes, 1976; $25: 566$ - 73.

4. Kleinman JC, Donahue RP, Harris MI, Finucane FF, Madans JH, Brock DB. Mortality among diabetics in a national sample. Am J Epidemiol 1988; 128 : 389 - 401.

5. Fein FF. Clinical manifestations of diabetic cardiomyopathy. In : Chatham JC, Forder JR, McNeill JH (eds.). The heart in diabetes, Norwell : Kluwer Academic Publ., 1996: 1 - 22 .

6. Keen H, Rose G, Pyke DA, et al. Blood sugar and arterial disease. Lancet 1965; 2 : 505 - 8.

7. Epstein FH, Ostrander LD, Johnson BJ, et al. Epidemiological studies of cardiovascular disease in a total community Tecumseh, Michigan. Ann Intern Med 1965; 62 : 1170 - 87.

8. Ostrander LD, Francis T, Hayner NSD, et al. The relationship of cardiovascular disease to hyperglycemia. Ann Intern Med 1965; $62: 1188$ - 98.

9. Pell S, D'Alonzo CA. Factors associated with long term survival of diabetes. J Am Med Assoc 1970; 214 : 1833 - 40.

10. Gordon T, Castelli WP, Hjortland MC, Kannel WB, Dawber TR. Diabetes, blood lipids and the role of obesity in coronary heart disease risk for women. The Framingham Study. Ann Intern Med 1977; $87: 393$ - 7 .

11. Kannel WB, McGee DL. Diabetes and cardiovascular risk factors : the Framingham Study. Circulation 1979; 59 : 8-13.

12. Stamler J, Wentworth D, Neaton J, Schoenberger JA, Feigal D. Diabetes and risk of coronary, cardiovascular, and all cause mortality : findings for 356,000 men screened by the multiple risk factor intervention trial (MRFIT). Circulation 1984; 70 (suppl) II : II-161.

13. Thompson SG, Greenberg G, Meade TW. Risk factors for stroke and myocardial infarction in women in United Kingdom as assessed in general practice : a case control study. Br Heart J 1989; 61 : 403 - 9.

14. Patarmian JO, Bradley RF. Acute myocardial infarction in 258 cases of diabetes : immediate mortality and five year survival. N Engl J Med $1965 ; 273 ; 455$ - 9.

15. Weitzman S, Wagner GS, Heiss G, Haney TL, Slomen G. Myocardial infarction site and mortality in diabetes. Diabetes Care, 1982; $5: 31$ - 5 .

16. Margolis JR, Kannell WS, Feinlieb M, Dawber TR, McNamara PM. Clinical features of unrecognized myocardial infarction : silent and asymptomatic : eighteen year follow up study : the Framingham Study. Am J Cardiol 1973; 31 : $1-7$

17. Oswald GA, Corcoran JS, Patterson DLH, Yudkin JS. The extent of coronary artery disease in diabetic patients with myocardial infarction : an ECG study. Diabetic Medicine $1986 ; 3: 541-4$.

18. Smith JW, Marcus FI, Serokman R. Prognosis of patients with diabetes mellitus after myocardial infarction. Am J Cardiol 1984; 54 : 718 - 21.

19. Orlander PR, Goff DC, Morrissey M, et al. The relation of diabetes to the severity of acute myocardial infarction and post myocardial infarction survival in Mexican-Americans and non-Hispanic Whites : the Corpus Christi Heart Project. Diabetes $1994 ; 43: 897$ - 902 .

20. Nesto RW, Phillips RT. Asymptomatic myocardial ischemia in diabetic patients. Am J Med $1986 ; 80:$ suppl 4C : 40-7.

21. Chiariello M, Indolfi C. Silent myocardial ischemia in patients with diabetes mellitus. Circulation 1996; 93 : 2089 $-91$.

22. Waller BF, Palumbo PJ, Lie JT, Roberts WC. Status of the coronary arteries at necropsy in diabetes mellitus with onset after 30 years. Am J Med 1980; 69 : 498- 507.

23. Vigorita VJ, Moore GW, Hutchins GM. Absence of correlation between coronary arterial atherosclerosis and severity or duration of diabetes mellitus of adult onset. Am J Cardiol $1980 ; 46: 535-42$.

24. Hochman JS, Phillips WJ, Ruggieri D, Ryan SF. The distribution of atherosclerotic lesions in the coronary arterial tree : Relation to cardiac risk factors. Am Heart J 1988; 116 : 1217 - 22 .

25. Dortimer AC, Shenoy PN, Shiroff RA, et al. Diffuse coronary disease in diabetic patients. Fact or fiction?. Circulation 1978; $57: 133-6$.

26. Vigorito C, Betocchi S, Bonzani G, et al. Severity of coronary disease in patients with diabetes mellitus. Angiographic study of 34 diabetic and 120 nondiabetic patients. Am Heart J 1980; $100: 782$ - 7 . 
27. Wilson CS, Gau GT, Fulton RE, et al. Coronary artery disease in diabetic and nondiabetic patients : a clinical and angiographic comparison. Clin Cardiol $1983 ; 6$ : 440 - 6 .

28. Lemp GF, Vander Zwaag R, Hughes JP, et al. Association between the severity of diabetes mellitus and coronary arterial atherosclerosis. Am J Cardiol 1987; 60 : 1015 - 9.

29. Stein B, Weitraub WS, Gebhart SSP, et al. Influence of diabetes mellitus on early and late outcome after percutaneous transluminal coronary angioplasty . Circulation 1995, $91: 979$ - 89.

30. Jacoby RM, Nesto RW. Acute myocardial infarction in the diabetic patients : pathophysiology, clinical course and prognosis. J Am Coll Cardiol 1992, 20 : 736 - 44.

31. Davies M, Bland J, Hangartner J, et al. Factors influencing the presence or absence of acute coronary thrombi in sudden ischaemic death. Eur Heart j 1989; $10: 203-8$.

32. MacRury S, Lowe G. Blood rheology in diabetes mellitus. Diabet Med 1990; 7 : 285 - 91.

33. Ostermann H, van der Loo J. Factors of the hemostatic system in diabetic patients. Haemostasis 1986; $16: 386$ 416.

34. Davi G, Catalano I, Averna M, et al. Thromboxane biosynthesis and platelet function in type II diabetes mellitus. $\mathrm{N}$ Engl J Med 1990; $322: 1769$ - 74.

35. Schneider DJ, Nordt TK, Sobel BE. Attenuated fibrinolysis and accelerated atherogenesis in type II diabetic patients. Diabetes 1993; $42: 1$ - 7 .

36. Serrano-Rios M, Perez A, Saban-Ruiz J. Cardiac complications in diabetes: World book of diabetes in practice. Princeton, NJ : Elsevier; $1986: 2$ : 169 - 78.

37. Banskota NK, Taub R, Zellner K, et al. Characterization of induction of protooncogene c-myc and cellular growth in human vascular smooth muscle cells in insulin and IGF-1. Diabete 1989; 38 : 123- 9.

38. Holmes DR Jr., Vlietstra RE, Smith HC, et al. Restenosis after percutaneous transluminal coronary angioplasty (PTCA) : a report from the PTCA Registry of the National Heart, Lung and Blood Institute. Am J Cardiol 1984, 53 : $77 \mathrm{C}-81 \mathrm{C}$.

39. Margolis JR, Krieger R, Glemser E. Coronary angiplasty : increased restenosis rate in insulin dependent diabetics. Circulation 1984; 70 (suppl II) : II-75 (abstract).

40. Simonton CA, Mark DB, Hinohara T, et al. Restenosis following successful angioplasty : a multivariable analysis of patient, procedure and coronary lesion- related risk factors. J. Am Coll Cardiol 1987; 9 : 184A (abstract).

41. Myler RK, Topol EJ, Shaw RE, et al. Multiple vessel coronary angioplasty : classification, results, and patterns of restenosis in 494 consecutive patients. Cathet Cardiovasc Diagn. 1987; $13: 1$ - 15.

42. Vandormael MG, Deligonul U, Kern MJ, et al. Multilesion coronary angioplasty : clinical and angiographic follow up. J Am Coll Cardiol 1987; $10: 246$ - 52

43. Hollman J, Badhwar K, Beck GJ, et al. Risk factors for recurrent stenosis following successful coronary angioplasty. Cleve Clin J Med 1989; $56: 517$ - 23.

44. Quigley PJ, Hlatky MA, Hinohara T, et al. Repeat percutaneous transluminal coronary angioplasty and predictors of recurrent stenosis. Am J Cardiol 1989; 63 : 409 - 13.
45. Deligonul U, Vandormael M, Kern MJ, et al. Repeat coronary angioplasty for restenosis : results and predictors of follow-up clinical events. Am Heart J 1989; 117 : 997 . 1002.

46. Lambert M, Bonan R, Cote G, et al. Multiple coronary angioplasty : a model to discriminate systemic and procedural factors related to restenosis. J Am Coll Cardiol 1988; $2: 310-14$.

47. Weintraub WS, Kosinski AS, Brown CL III, King SB III. Can restenosis after coronary angioplasty be predicted from clinical variables?. J Am Coll Cardiol $1993 ; 21$ : 6 - 14 .

48. Serruys $P$, de Jaegere P, Kiemeneij F, et al. For the BENESTENT Study Group. A comparison of balloon expandablestent implantation with balloon angioplasty in patients with coronary artery disease. N Engl J Med 1994; 331 : 489 - 95.

49. Fischman DL, Leon MB, Baim DS, et al. For the Stent REStenosis Study Investigators. A randomized comparison of coronary-stent placement and balloon angioplasty in the treatment of coronary artery disease. N Engl J Med 1994; $331: 496$ - 501

50. Popma JJ, Mintz GS, Satler LF, et al. Clinical and angiographic outcome after directional coronary atherectomy. Am J Cardiol 1993; 72 : 55E - 64E.

51. Carrozza JP, Kuntz RE, Fishman RF, et al. Restenosis after arterial injury caused by coronary stenting in patients with diabetes mellitus. Ann Intem Med 1993; 118 : 344 - 9.

52. Rabbani LE, Edelman ER, Ganz P, et al. Relation of restenosis after excimer laser angioplasty to fasting insulin levels. Am J Cardiol 1994; 73 : 323 - 7.

53. Aronson D, Bloomgarden Z, Rayfield EJ. Potential mechanisms promoting restenosis in diabetic patients. J Asm Coll Cardiol 1996; $27: 528$ - 35.

54. Anderson HV. Restenosis after coronary angioplasty. Dis Month 1993; $39: 613$ - 70.

55. Topol EJ, Califf RM, Weisman HF, et al. Randomized trial of coronary intervention with antibody against platelet $\mathrm{IIb} / \mathrm{III}$ integrin for reduction of clinical restenosis : results at 6 months. Lancet 994; $343: 881-6$.

56. Ip JH, Fuster V, Israel D, et al. The role of platelets, thrombin, and hyperplasia in restenosis after coronary angioplasty. J Am Coll Cardiol 1991; 17 : 77B - 88B.

57. Alderman EL, Corley SD, Fisher LD, et al. And the CASS Participating Investigators and Staff. Five-year angiographic follow-up of factors associated with progression of coronary artery disease in the Coronary Asrtery Surgery Study (CASS). J Am Coll Cardiol 1993; 22 : 1141 - 54.

58. Pocock SJ, Henderson RA, Rickards AF, et al. Meta-analysis of randomized trials comparing coronary angioplasty with bypass surgery, Lancet 1995; $346: 1184$ - 9.

59. CABRI Trial Participants. First year results of CABRI (Coronary Angiolasty versus Bypass Revascularization Investigation). Lancet $1995 ; 346: 1179$ - 84.

60. RITA Trial Participants. Coronary angioplasty versus coronary bypass surgery : the Randomized Intervention Treatment of Angina (RITA) Trial. Lancet 1993; $343: 573$ $-80$.

61. King SB, Lembo NJ, Kosinski AS, et al. A randomized trial comparing coronary angioplasty with coronary bypass surgery. N Engl J Med 1994; 331 : 1044 - 50. 
62. Hamm CW, Riemers J, Ischinger T, et al. A randomized study of coronary angioplasty compared with bypass surgery in patients with symptomatic multivessel coronary disease. N Engl J Med 1994; 331 : 1037 - 43.

63. Puel J, Karouny, Marco J, et al. Angioplasty versus surgery in multivessel disease : immediate results and in-hospital outcome in a randomized prospective study. Circulation 1992; 86 (suppl I) : 372 .

64. Hueb W, Arie S, Oliveira SA, et al. The Medicine, Angioplasty, or Surgery Study (MASS) : a prospective randomized trial for single proximal left anterior descendijng artery stenoses. J Am Coll Cardiol (in press)

65. Goy JJ, Eeckhout E, Burnan B, et al. Coronary Angioplasty versus left internal mammary artery grafting for isolated proximal left anterior descending artery stenosis. Lancet 1994; $343: 1449$ - 53.

66. Rodriguez A, Boullon F, Perez-Balino N, et al. Argentine randomized trial of percutaneous transluminal coronary angioplasty versus coronary artery bypass surgery in multivessel disease (ERACI) : in hospital results and 1 year follw-up. J Am Coll Cardiol 1993; 22 : 1060 - 7.

67. Stables RH, Sigwart U. CABG v PTCA in multi-vessel disease : angiographic insights. Eur Heart J 1996; 17 : 140 1141 .
68. Ruprecht HJ, Hamm C, Ischinger T, et al. on behalf of the GABI Study Group. Angiographic follow-up results of a randomized study on angioplasty versus bypass surgery (GABI Trial). Eur Heart J 1996; 17 : 1192 - 8.

69. The Bypass Angioplasty Revasculatrization Investigation (BARI) Investigators. Comparison of coronary bypass surgery with angioplasty in patients with multivessel disease. N Engl J Med 1996; 335 : 217 - 25.

70. Rihal CS, Yusuf S. Coronary artery disease : drugs, angioplasty, or surgery ?. Br Med j 1996; $312: 265$ - 6.

71. National Diabetes Data Group. Classification and diagnosis of diabetes mellitus and other categories of glucose intolerance. Diabetes 1979; $287: 1039$ - 57

72. Campeau L. Grading of angina pectoris. Circulation 1975; $54: 522$ - 3 .

73. Ryan TJ, Faxon DP, Gunnar RM, et al. Guidelines for Percutaneous Transluminal Coronary Angioplasty. ACC/AHA Task Force report. J Am Coll Cardiol 1988; 12 : $529-54$

74. Santoso T, Trisnohadi HB, Wangge M. PTCA in the latest 1000 patients. KOPAPDI - Padang, 1996. (abstract). 